\title{
A Severe Microsporidian Disease in Cultured Atlantic Bluefin Tuna (Thunnus thynnus L.)
}

Alejandro López-Verdejo ( $\square$ alexlopez050290@gmail.com )

Cavanilles Institute of Biodiversity and Evolutionary Biology, University of Valencia https://orcid.org/0000-0003-1395-0278

Francisco E. Montero

Cavanilles Institute of Biodiversity and Evolutionary Biology, University of Valencia

Fernando De la Gándara

Instituto Espanol de Oceanografia Centro Oceanografico de Murcia

Miguel A. Gallego

Instituto Espanol de Oceanografia Centro Oceanografico de Murcia

Aurelio Ortega

Instituto Espanol de Oceanografia Centro Oceanografico de Murcia

Juan Antonio Raga

Cavanilles Institute of Biodiversity and Evolutionary Biology, University of Valencia

José F. Palacios-Abella

Cavanilles Institute of Biodiversity and Evolutionary Biology, University of Valencia

\section{Research}

Keywords: Microsporidia, Marinosporidia, Glugeida, Glugea thunni new taxa, aquaculture, Osteichthyes, Scombridae, xenoma.

Posted Date: April 7th, 2021

DOI: https://doi.org/10.21203/rs.3.rs-389325/v1

License: (c) (i) This work is licensed under a Creative Commons Attribution 4.0 International License. Read Full License 


\section{Abstract}

One of the most promising aquaculture species is the Atlantic bluefin tuna ( Thunnus thynnus ) with high market value; disease control is crucial to prevent and reduce mortality and monetary losses. Microsporidia Balbiani, 1882 (Fungi) are a potential source of damage to bluefin tuna aquaculture. A new microsporidian species is described from farmed bluefin tunas from the Spanish Mediterranean. This new pathogen is described in a juvenile associated with a highly severe pathology of the visceral cavity. Whitish xenomes from this microsporidian species were mostly located at the caecal mass and ranged from 0.2 to $7.5 \mathrm{~mm}$. Light and transmission electron microscopy of the spores revealed mature spores with an average size of $2.2 \times 3.9 \mu \mathrm{m}$ in size and a polar filament with 13-14 coils arranged in one single layer. Phylogenetic analysis clustered this species with the Glugea spp. clade. The morphological characteristics and molecular comparison confirm that this is a novel microsporidian species, Glugea thunni sp. nov. The direct life cycle and the severe pathologies observed makes this parasite a hard risk for bluefin tuna cultures.

\section{Introduction}

One of the main issues for the management of fish cultures is disease control, often subjected to new pathologies related to unknown pathogens (Woo 2006). The Atlantic bluefin tuna (ABT, Thunnus thynnus) is one of the most promising new species in Mediterranean aquaculture, due to its large size, fast growth and high market value. In fact, bluefin tunas (Thunnus spp.) are some of the highest market value fishes worldwide (FAO 2018, 2020). Despite the recent development of the culture of this species this industry generated 127,6 million euros in Europe in 2018, with an annual percentage value of $60,4 \%$, with Spain being the top producer in Europe (the second Thunnus spp. highest producer, worldwide, after Japan) (APROMAR 2020). The culture of this species is still based on the fattening of juveniles captured in the natural environment since, although the closure of the life cycle has been achieved in captivity, no profitable production levels have been achieved yet (De la Gándara et al. 2016, Ortega and De la Gándara 2017, FAO 2018, APROMAR 2020).

A total of 89 different parasites have been reported in ABT (Munday et al. 2003, Mladineo et al. 2011, Mladineo and Lovy 2011, Culurgioni et al. 2014, Palacios-Abella et al. 2015, Rodriguez-Llanos et al. 2015), including some severe threats to bluefin tuna culture such as caligid copepods, monogeneans and aporocotylid trematodes, (Mladineo et al. 2008, Hayward et al. 2009, Ogawa et al. 2011, Shirakashi et al. 2012, Palacios-Abella et al. 2015). Some other pathogens described in $\mathrm{ABT}$, such as microsporidians (Fungi), are also potentially damaging to bluefin tuna aquaculture, especially when this activity is expanding and increasing production. Fungi are usually external pathogens of fish and only a few can affect internal organs (Woo and Bruno 2011). Microsporidia Balbiani, 1882 are obligate intracellular parasites that are able to infect a wide variety of hosts, including many species of fish (Mathis et al. 2015).

Microsporidia were not originally considered as fungi, since molecular evidence showed their close phylogenetical relationship and finally microsporidian were included among them (Thomas et al. 1996; Hirt et al. 1999; Van de Peer et al. 2000). In 2006, microsporidians were nomenclaturally recognized as fungi in The International Code of Botanical Nomenclature (Vienna Code) (McNeill et al. 2006), however in 2009, they were proposed to be excluded from the International Code of Botanical Nomenclature (Currently called International Code of Nomenclature for algae, fungi, and plants (Shenzhen Code), despite their fungal nature (Redhead et al. 2009, Turland et al. 2018).

Currently, 18 genera of microsporidians infecting fish have been described (Azevedo et al. 2016). Some microsporidian species are considered a real issue for aquaculture by causing major diseases and mortality of the fish which consequently has a negative economic impact (Bulla and Cheng 1976, Kent et al. 2014, Ryan and Kohler 2016). Glugea Thélohan, 1891 is one of the microsporidian genera with one of the highest number of species, with at least 30 species infecting various organs in the fish hosts (Azevedo et al. 2016, Lom 2002, WoRMS 2021). Among the parasites described in bluefin tunas, the only microsporidian species reported to date are Microsporidium sp. and M. milevae Mladineo \& Lovy, 2011, infecting the muscle of T. orientalis and the intestine of $T$. thynnus, respectively, with no relevant pathologies reported (Zhang et al. 2004, Mladineo and Lovy 2011).

This study is focused on a new microsporidian disease found in an ABT culture in the Spanish Mediterranean. The parasite was associated with severe visceral infection compromising fish survival and possibly causing consumer rejection. The microsporidian and related pathologies are described using morphological and molecular analyses, with the aim of providing diagnostic tools. The possible transmission path is discussed, providing recommendations to avoid this harsh disease.

\section{Materials And Methods}

\section{Host and parasites sampling}

Parasites were observed during a routine control in one dead juvenile ABT. Tuna belonged to an experimental ABT stock born in the Marine Aquaculture Plant of the facilities of Spanish Institute of Oceanography (IEO) located in Mazarrón, (Murcia, SE Spain) from eggs collected from reproductive tunas maintained in sea cages. Larvae were reared in land-based facilities until 45 days (around $10 \mathrm{~g}$ wet weight), and then moved to sea cages placed off San Pedro del Pinatar (Murcia, SE Spain). Tunas were fed on thawed bait, mainly European pilchard (Sardina pilchardus) and round sardinella (Sardinella aurita). Parasites were found in November 2017, when tunas were 5 months old (about $30 \mathrm{~cm}$ of total length and $800 \mathrm{~g}$ of wet weight). The infected tuna was dissected and analysed in fresh with the naked eye. Samples of the infected tissues and encysted xenomas were collected and fixed in both formaldehyde $10 \%$ and glutaraldehyde $2.5 \%$ in cacodylate buffer $0.1 \mathrm{M} \mathrm{(pH} \mathrm{7.4} \mathrm{v/v)} \mathrm{for} \mathrm{posterior} \mathrm{light} \mathrm{and} \mathrm{electron} \mathrm{microscopy} \mathrm{analyses,} \mathrm{respectively.} \mathrm{Some} \mathrm{xenomas} \mathrm{were} \mathrm{also} \mathrm{fixed}$ in absolute ethanol for molecular study. Formaldehyde samples were also examined with a stereomicroscope (Leica MZ6 at 20-40x) under laboratory conditions.

\section{Microscopy techniques}


The isolated encysted xenomas were measured previous to the excision. The spores were first observed in fresh smear preparations with light microscopy (Leica DMR). Part of the specimens fixed in formaldehyde were embedded in paraffin and cut in $5 \mu \mathrm{m}$ sections with a Leica RM $2125 \mathrm{RT}$ microtome and then stained in hematoxylin-eosin for further observations.

Glutaraldehyde fixed cysts were cut in semi-thin and ultrathin sections in the Central Service for Experimental Research (SCSIE) of the University of Valencia. Fixed cysts were washed three times and then postfixed in osmium tetroxide $1 \%$ in cacodylate buffer $0.1 \mathrm{M}$. After washing with the sodium cacodylate, cysts were dehydrated in increasing concentrations of ethanol and embedded in epoxy resin. Sections were performed in a Leica VT1200S ultramicrotome to obtain semi-thin $(2 \mu \mathrm{m})$ and ultrathin $(60-70 \mathrm{~nm})$ sections. Semi-thin sections were stained in toluidine blue and ultrathin sections (60-70 $\mathrm{nm})$ in uranyl acetate (20 $\mathrm{min}$ ) and lead citrate (5 min). Images were acquired in the Electron Microscopy Unit of the SCSIE with the Transmission Electron Microscope (JEOL JEM 1010 with AMT RX80 (8Mpx) digital camera) operated at 80kV. Measurements were obtained from 20 individuals, except when otherwise indicated.

\section{Molecular data}

For the molecular study DNA extraction was performed with the ®Blood \& Tissue kit (Quiagen, Venlo, The Netherlands), directly from the excised cyst (submitted previously to a mechanical rupture process) and following the manufacturer's instructions.

The 16S gene of the ribosome was amplified by PCR with the following primer pairs: (V1f (5'-CACCAGGTTGATTCTGCC-3') with HG5F_rev (5'TCACCCCACTTGTCGTTA-3'), and HG4F (5'-CGGCTTAATTTGACTCAAC-3') with HG4R (5'-TCTCCTTGGTCCGTGTTTCAA-3'). The PCR were performed in $20 \mu$ l reactions with $3 \mu \mathrm{l}$ of DNA sample, $1.6 \mu \mathrm{l}$ of each primer at $5 \mathrm{mM}$ and $10 \mu \mathrm{l}$ of MyFi Mix (Bioline Ltd., London, United Kingdom). The thermocycling amplification program consisted of a preliminary denaturation step at $94^{\circ} \mathrm{C}(5 \mathrm{~min})$ followed by $40 \mathrm{cycles} \mathrm{of} 94^{\circ} \mathrm{C}(50 \mathrm{sec}), 50^{\circ} \mathrm{C}(50 \mathrm{sec}), 72^{\circ} \mathrm{C}(2 \mathrm{~min})$ ending with a final extension step at $72^{\circ} \mathrm{C}(10 \mathrm{~min})$ and then preserved at $4^{\circ} \mathrm{C}$. The amplicons were visualized in a $1 \%$ agarose gel with GelRed stain on a $\sim 35 \mathrm{~min}, 95 \mathrm{~V}$ electrophoresis.

The sequencing was performed using the same PCR primers and carried out at Macrogen Europe Inc. (Amsterdam, The Netherlands) on a 3730xI DNA Analyzer (Applied Biosystems, Foster City, USA). The obtained sequences were assembled using BioEdit and submitted to the Basic Local Alignment Search Tool (BLAST) on GenBankTM to check for sequence identity.

\section{Phylogenetic analysis}

The newly generated sequence was aligned with available sequences retrieved from GenBank (Table 1). We performed two different alignments varying the sequences used and their length, bearing in mind the limitations imposed by the differences in the length among the sequences of the selected species and the differences of base pairs in the alignment with the shortest sequences (Tables 2 and 3). Sequences were aligned with MUSCLE (Edgar 2004) implemented in MEGA v7 (Kumar et al. 2016). Non-homologous regions were removed prior to analyses using Gblocks implemented in SEAVIEW v4.6.1 (Gouy et al. 2010). Neighbour-joining (NJ), maximum likelihood (ML) and Bayesian inference (BI) analyses were used to explore the relationships of Glugea thunni sp. nov. in relation to the other available sequenced species of Glugea. Neighbour-joining analyses of Kimura-2-parameter distances using 1,000 bootstrap resampling used to estimate the nodal support. BI analyses were carried out with MrBayes v 3.2.3 (Ronquist and Huelsenbeck 2003) and ML analyses were performed with PhyML 3.0 (Guindon et al. 2010) with a non-parametric bootstrap validation based on 1,000 replicates. The general time-reversible model with gamma distributed among-site rate variations $(G T R+\Gamma$ ) was estimated as the best-fit nucleotide substitution model using jModelTest 2.1 (Guindon and Gascuel 2003 , Darriba et al. 2012). Posterior probability distributions were generated using Markov Chain Monte Carlo (MCMC) method. MCMC searches were run for $10,000,000$ generations on two simultaneous runs of four chains and sampled every 1,000 generations. The 'burn-in' was set for the first 2,500 sampled trees which were discarded prior to analyses. The trees were visualized with FigTree v 1.4.2 (Rambaut 2012).

\section{TAXONOMY}

Glugea thunni López-Verdejo, Montero, de la Gándara, Gallego, Ortega, Raga, Palacios-Abella, sp. nov.

Etymology: The species refers to Thunnus the genus of the type host species.

Diagnosis: Glugea thunnisp. nov. can be distinguished from other congeneric species by the combination of morphological traits such as spore measurements and number of polar filament coils, and the new host species (and family) for the genus Glugea. The new species can be distinguished from the other microsporidians in Thunnus spp. (Microsporidium sp. and M. milevae) by the i) infection site (mesenteries of caecal mass and viscera vs. trunk muscle and intestinal muscularis mucosa); ii) cyst traits (subspherical / up to $7.5 \mathrm{~mm}$ vs spindle-shaped / up to $6 \mathrm{~mm}$ and spherical-elongated / $2.1 \times 0.8 \mathrm{~mm}$ ); iii) and spore traits in fresh (ovoid to ellipsoidal / 2.0-2.5 × 3.6-4.5 $\mu \mathrm{m} v s$. oval to pyriform / 2.4-2.9 × 1.2-1.7 $\mu \mathrm{m}$ and pyriform / $2.45 \pm 0.28 \times 4.88 \pm 0.31$ $\mu \mathrm{m})$; and iv) polar filament arrangement in spores (13-14 coils in single row in $G$. thunni sp. nov. vs. 12-17 coils in two rows in $M$, milevae, not indicated in Microsporidium sp.) (Zhang et al. 2004, Mladineo and Lovy 2011).

Type: Spain:Murcia, off San Pedro del Pinatar, 3749' 32.0"N 044'54.3"W, on Thunnus thynnus (Linnaeus, 1758) (Perciformes, Scombridae), November 2017. (Histological resin and paraffin sections deposited in the Spanish Museum of Natural Sciences (MNCN-CSIC), Madrid, Spain. Accession numbers: \#\#\#\#\#\#\# for the holotype and \#\#\#\#\#\# for the paratype. The remaining material deposited in the Parasitological Collection of the Cavanilles Institute of Biodiversity and Evolutionary Biology, University of Valencia, Spain. Representative sequence of 16S rDNA (1751bp) of G. thunni sp. nov was uploaded to GenBank database under the Accession number \#\#\#\#\#\#.

Description: Xenomes whitish, subspherical to ellipsoidal, in cysts mostly associated to the caecal mass, with diameters ranging from 0.2 to 7.5 mm, with an average size of $3.3 \mathrm{~mm}(\mathrm{n}=40)$; some xenomes also in liver, peritoneum and cloaca (Fig. 1A). In fresh smears, spores arranged within parasitophorous 
vesicles (in groups of approximately 3 to 100 , Figs. 1B and 1C). Spores ovoid to ellipsoidal in shape measuring $2.2 \times 3.9(2.0-2.5 \times 3.6-4.5) \mu m(n=10)$ in fresh. Some larger spores $(2.4 \times 6.5(1.6-2.7 \times 6.0-6.8) \mu \mathrm{m})(\mathrm{n}=10)$ also found, elongated and/or bent and fusiform in shape (Figs. $1 \mathrm{C}$ and $2 \mathrm{E})$. In semi-thin sections, ovoidal spores measuring $2.1 \times 3.8(1.9-2.5 \times 3.5-4.0) \mu \mathrm{m}(\mathrm{n}=10)$ and large fusiform spores $2.6 \times 6.2(2.5-2.7 \times 5.9-6.4) \mu \mathrm{m}(\mathrm{n}=10)(\mathrm{Fig} .2 \mathrm{E})$. In TEM, xenomes with numerous spores enclosed within parasitophorous vacuoles with faint membranes together with degenerative host cells (Fig. $3 \mathrm{~A}$ ). Mature spores measuring $2.22 \times 3.62(1.82-2.44 \times 3.14-4.26) \mu \mathrm{m}(n=10)$. Developmental stages of $G$. thunni sp. nov. also observed (Figs. 3B and C): early sporoblasts irregular and thin-walled whilst immature spores ovoid to fusiform, somewhat larger than mature spores $(2.38 \times 5.16(2.01-2.28 \times 4.11-5.36)$ $\mu \mathrm{m} ; \mathrm{n}=3$ ) with well-defined spore wall, although smooth and thinner. Mature spores ovoid with a rugous surface. Wall of mature spores double-layered, formed by an electron-lucent endospore and a thin electron-dense exospore with an altogether thickness of $0.113(0.079-0.158) \mu \mathrm{m}$ (Figs. 4A and B). Nucleus, irregular in shape, medial, between posterior vacuole and apical polaroplast (Fig. 4A). Posterior vacuole occupying most of the second half of the mature spore, almost completely surrounded by the polar filament with 13-14 coils in one single layer (Figs $4 \mathrm{~A}$ and $\mathrm{C}$ ) ending in a subapical concave anchoring disc (0.320-0.351 $\mu \mathrm{m}$ in diameter, 0.077-0.078 thickness; $\mathrm{n}=2$ ) (Fig. 4B).

Host. Thunnus thynnus.

Habitat. Aquaculture sea-cage off San Pedro del Pinatar, Murcia, Spain.

Distribution: Western Mediterranean.

\section{Results}

\section{Clinical signs and diagnosis}

The infected fish was found freshly dead with a conspicuously swollen abdomen (Figure 1A). The rest of the tuna in the routine control did not show this alteration. The intestinal zone of the abdominal cavity was occupied by highly numerous whitish xenomes. some of them showed up externally (see detail in figure 1A). Several cysts showed melanization in dark brownish or yellowish spots. In sections, cysts were found in the intestinal mesentery, in clusters associated to the caecal mass (Fig- 2A). Xenomes appeared encapsulated by a layer of host cells, with spores and sporoblasts grouped within parasitophorous vacuoles together with degenerative host cells (nuclei observed in TEM, see Fig. 3A). Cyst walls had an external host cell layer and an internal acellular layer; both layers showed different thickness in each cyst (see Figs. 2B and D). Eosinophylic granule cells and macrophages were observed within the cellular layer (Fig. 2D). Several xenomes exhibited peripheral areas of melanization (Figs. 2B and C).

\section{Molecular and phylogenetic analysis}

A 16S rDNA sequence of 1751 bp was obtained for the new Glugea specimens. Firstly, was compared to the database sequences from Genbank with the BLAST tool. The most similar sequences to the new one here obtained were AF044391 (G. anomala) and GQ203287 (G. hertwigi) with $100 \%$ query coverage and a similarity of 98 and $99 \%$ respectively, showing very low differences among species. Tables 2 and 3 show the p-distances and differences of pair bases among the sequences used in the performed alignments. In the first rDNA alignments 774 informative positions were included (short sequences) comprised of 22 sequences in the ingroup with Brachiola algerae (Coyle et al. 2004) used as outgroup. Due to the short length of the trimmed sequences, the differences of bp between some of the sequences was 0 (Table 2).

The result of $\mathrm{BI}$ and $\mathrm{ML}$ from this alignment solved the trees in the same way but the lack of support in the lower relationships must be highlighted. In both $\mathrm{BI}$ and ML there is a basal clade formed by Microgemma species (partial 16S), then the next clade that separates is the one formed by Loma species. Afterwards we can observe a bifurcation from which two groups appear. In the first group there is one clade formed by Pleistophora species and a second clade made up of six Glugea species (G. arabica, G. eda, G. epinephelusis, G. jazanensis, G. nagelia, and G. serranus), species in Group 2 sensu (Mansour et al. 2016) (G2). The second group is made up of the remaining Glugea species (G. anomala, G. atherinae, G. gasterostei, G. hertwigi, G. plecoglossi, G. sardinellensis and G. stephani), species in Group 1 sensu (Mansour et al. 2016) (G1) including the new Glugea thunnisp. nov. (Figure 5).

The second alignment was performed with longer sequences (1713 informative positions), including nine sequences in the ingroup and $B$. algerae (Edgar 2004) as outgroup. By using these longer sequences, differences in bp not observed in the previous shorter alignment were now shown, such as between $G$. hertwigi and G.thunni sp. nov. (Table 3). In the same way, both $\mathrm{BI}$ and $\mathrm{ML}$ resulted in similar tree, although in this case high nodal supports were obtained, in contrast with the previous trees that had more taxa but shorter sequences. The first taxa that diverges is $L$. embiotocia, then two groups, one formed by and Pleistophora typicalis basal to G. arabica, G. eda, G. nagelia and G. serranus and the second one formed by G. hertwigi, G. anomala and G. thunni sp. nov. (Figure 6).

\section{Discussion}

Increasing fish demand worldwide makes it necessary to impel the development of the aquaculture industry to compensate for the stagnation of fisheries extraction (FAO 2020). The expansion of aquaculture of new fish species and geographical areas brings new health challenges that must be faced with research in fish diseases and wellness. Among pathogens, parasites go often unnoticed as natural factors affecting fish populations, however natural mortalities and decreases in fish captures related to parasite outbreaks have sometimes been reported (Lloret et al. 2012). In contrast, parasitoses are known as main threats to several fish cultures worldwide, as several parasites proliferate in culture conditions provoking abnormally severe pathologies (Dyková 2006, Ogawa 2015).

Mediterranean aquaculture has been focused in two fish species, the European seabass Dicentrarchus labrax and the gilthead seabream Sparus aurata, both cultures affected by several parasites; e.g. the microsporidian Enterospora nucleophila and the monogenean Diplectanum aequans (in D. labrax) or the 
myxozoan Enteromyxum leei and the monogenean Sparicotyle chrysophrii (in S. aurata) (Dezfuli et al. 2007, Fleurance et al. 2008, Antonelli et al. 2010, Palenzuela et al. 2014). With the aim of diversifying Mediterranean aquaculture, new fish cultures are being developed, including highly valuable species of fast growth such as the ABT, (which life cycle has been closed in culture conditions) (De la Gándara et al. 2017). The culture of the bluefin tuna species (Thunnus spp.) has experienced a fast expansion worldwide, partly caused by the overexploited stocks. In both wild and cultured tunas, parasites are known as the main pathological agents, including external (as copepods related to mild to severe damage; see Hayward et al. 2009) and internal parasitoses (aporocotylid trematodes causing significative mortalities in tuna juveniles (Ogawa et al. 2011, Shirakashi et al. 2012). The only microsporidian reported to date in the ABT is M. milevae, although it has only been found in isolated episodes (Mladineo et al. 2011, Mladineo and Lovy 2011). The disease herein described is provoked by a different microsporidian species (G. thunni sp. nov.) related to conspicuous and severe pathologies in fish and may become a relevant problem for the culture of the bluefin tunas, in particular for the Mediterranean ABT.

Currently, 35 species of Glugea have been described (Azevedo et al. 2016, Mansour et al. 2020). Glugeathunni sp. nov. possess the morphological traits of the genus Glugeasensu Lom (Lom 2002): unpaired nuclei throughout development, thin membrane-like wall of parasitophorous vesicle, monomorphic mature spores and isofilar polar tube coiled in single row. This diagnosis would include the new described species in the subclade G1 described by Mansour et al. (Mansour et al. 2016) including mostly Mediterranean parasites. However, Lom's (Lom 2002) generic description would not include the six congeneric species more recently described, mostly from the Red Sea and Arabian Gulf, included in the subclade G2 (Mansour et al. 2016), in which polar tubes are arranged in several rows (this trait not described in G. epinephelusis) (Zhang et al. 2004, Wu et al. 2005, Mansour et al. 2016). Within the subclade G1, other similar species to the new Glugea species are G. anomala, G. gasterostei, G. hertwigi, G. plecoglossi, G. sardinellensis and G. stephani, based on the range of number of coils and the spore width range; however, the spore of G. thunni sp. nov. is shorter in mean (Canning et al 1982, Takvorian and Cali 1983, Takahashi and Egusa 1977a, Lovy et al. 2009, Tokarev et al. 2015, Mansour et al. 2016). Within this group, the most similar species is G. sardinellensis with a similar spore shape and the same range of number of coils (13-14): however, the new species is different from G. sardinellensis by the above-mentioned shorter spore and the much larger maximum size of the xenomas (probably related with the host size: T. thunnus vs. Sardinella aurita).

Regarding the molecular results from both phylogenetic trees with long and short sequences, the distribution of the Glugea species in the present study were identical to the ones observed in (Mansour et al. 2016). Glugeathunni sp. nov. is included in the G1 group cited above, which is congruent with the morphological similarity. However, the relationships between species within this $\mathrm{G} 1$ group are not well resolved due to the short sequences available and the low genetic divergences obtained in the SSU-LSU genes (Figure 5 and Table 2). The two closest species genetically to G. thunni sp. nov. are G. hertwigi, from the intestine of Osmerus epperlanus and G. anomala, from the muscle of Gasterosteus aculeatus. Low but significant differences among these species are observed only by using longer sequences of $G$. anomala, G. hertwigi and $G$. thunni sp. nov. (used in the second alignment of present work): p-distances range from $0.4 \%$ of differences between G. thunni sp. nov. vs. G. hertwigi to $1.1 \%$ from G. hertwigi vs. G. anomala (Figure 6 and Table 3 ). The phylogenetic tree resulting from the long sequences revealed $G$. anomala as the closest species to $G$. thunni sp. nov., instead of G. hertwigi. Surprisingly, contrary to the morphological information, G. sardinellensis was the most clearly distant species to $G$. thunni sp. nov. among those of the G1 group with at least $2.4-2.7 \%$ of differences in respect to their other relatives (Figure 5 and Table 2). An additional sequence labelled as "G. plecoglossi" (KY882286, unpublished) exists in GenBank. This microsporidian could have been inaccurately identificated, as its sequence is different to those of $G$. plecoglossi from other studies but almost identical to G. thunni sp. nov. In absence of morphological confirmation, molecular results indicate that "G. plecoglossi" (KY882286) and G. thunni n. sp could be the same species. This information could be useful to determine the transmission path in ABT cultures, as " $G$. plecoglossi" (KY882286) was found in a clupeid (Sardina pilchardus, Clupeidae), a fish that is commonly used as bait to feed tuna in the Spanish farms (e.g., Sardinella aurita, Clupeidae). It is worth mentioning that the other microsporidia species in bluefin tunas, Microsporidium sp. and M. milevae (Zhang et al. 2004, Mladineo and Lovy 2011), are not included in these comparisons as they are not genetically or morphologically close.

In recent years, molecular data has become an essential tool for taxonomical analyses of the microsporidia, however most of the species are only characterized by their ultrastructure, xenoma traits, host specificity or life cycle (Corradi and Keeling 2009, Azevedo et al 2016). The fact that only 14 sequences of Glugea spp. (including G. thunnisp. nov.) are available in Genbank makes it necessary to combine molecular analyses and other biological traits to elucidate the phylogenetic relationships of the microsporidians. In this context, the morphological and molecular classifications must be congruent. Several G/ugea species recently described, which have been genetically included in G2 according to Mansour 2016, do not accomplish one of the diagnostic traits of the genus, which is the arrangement of polar tubes in a single row (Lom 2002) (several rows in G2). Based on the different morphology and the separation of G1 and G2 in phylogenetic trees, the inclusion of G2 species within genus Glugea seems doubtful. We also strongly recommend obtaining longer sequences, with similar coverage, in order to obtain more solid results to clarify the phylogenetic relationships among this diverse parasite group.

According to (Azevedo et al 2016), the species of Glugea either have preference for smooth musculature or connective tissues of visceral organs. Glugea thunni sp. nov. shares this habitat preference with G. hertwigi, one of the phylogenetically closest species (Lovy et al. 2009). The infection of visceral mesenteries in this investigation allowed a wide parasite dispersion, not only in the caecal mass, but also in other intestinal regions and the liver; moreover, this extensive infection had to have been achieved in a relatively short time, due to the young age of the specimen (five months). The impact of this parasite seems different to that of the other microsporidians in bluefin tunas; Microspora sp. was reported in the muscle of T. orientalis (Zhang et al 2010), which could affect product value, while M. milevae infects the muscularis mucosa of T. thynnus (Mladineo and Lovy 2011), which could affect the intestinal function. However, these Microspora spp. infections seem more localized than that which is associated to $G$. thunni sp. nov., and therefore their consequences appear to be milder. Moreover, the massive alterations of viscera associated with $G$. thunni sp. nov. is likely to cause rejection by the consumer.

The new species shows a high capability to spread within the host, reaching a high intensity, however the parasite was found in only one fish of the sea cage. Transmission of fish microsporidians is described as trophic and direct, although some crustaceans could also take part in the life cycle (Lom and Nilsen 2003, Lom and Dyková 2005). In culture conditions, a small number of crustaceans of the zooplankton can reach sea cages, but the most probable infection path of the parasite is through bait or by cannibalism. The transmission capability of these parasites among different tunas has been quite limited, however, in view of the severe consequences of the parasite, prevention measures are needful. The removal of dead fish is highly recommended, as well as, when 
possible, ill and moribund fish. Nonetheless, infected food appears to be the main issue to deal with this disease, as it is the most probable pathway for this parasite to have entered in the cultures, as tunas of this study were not captured from the wild for fattening. These ABTs were born in captivity and fed with thawed bait, mostly clupeids. Glugea thunni sp. nov. could also infect clupeids as although the type host is $T$. thynnus, clupeids are frequent hosts of Glugea spp. (Mansour et al 2016) and, more importantly, the new species sequence is the same as KY882286 in Genbank, an unpublished sequence apparently wrongly identified as "G. plecogloss" from Sardina pilchardus (Clupeidae). Therefore, an adequate management of the bait is highly recommendable. Bait is routinely frozen (approximately, $-18^{\circ} \mathrm{C}$ ) to avoid horizontal transmission of anisakid nematodes, an important concern for consumer health. This process would also affect $G$. thunni sp. nov. infectivity. The development of $G$. plecoglossi is known to be slowed at $-16^{\circ} \mathrm{C}($ Takahashi and Egusa $1977 \mathrm{~b})$ and $G$. stephani experimental infection failed at $-15^{\circ} \mathrm{C}$ (Olson 1976). However, it is known that some microsporidians show a high resistance to low temperatures (up to $-80^{\circ} \mathrm{C}$ ) (Maddox and Solter 1996). The harshness of this parasite makes it necessary to study its viability at low temperature.

In summary, it is very important to highlight the potential degree of damage of this microsporidian in cultures of ABT, one of the most expensive and appreciated fish worldwide. Nowadays, there are no effective treatments against microsporidian in fish, except for some sporadic and inconclusive reports (toltrazuril for G. anomala and fumagilin for G. plecoglossi, see Fleurance et al. 2008). Other fungicides or new therapeutic strategies to control microsporidian diseases are needed. Thus, prevention appears to be the most recommendable way to cope with disease, which requires knowledge of the transmission paths. Future investigations should therefore focus on: i) searching for the parasites in clupeids of bait to determine their role as possible disease entry; ii) studying the effect of low temperatures in the microsporidian infectivity; and iii) finding alternative ways to treat the food to inactivate the parasite. Despite the lack of this information, avoiding dangerous practices as the use of fresh and never frozen bait is highly recommendable to prevent this disease, especially when clupeid fishes are used as food.

\section{Abbreviations}

ABT: Atlantic bluefin tuna (Thunnus thynnus); AD: anchoring disk; En: wall endospore; Ex: wall exospore; HN: host cell nucleus; IS: immature spores; MM: mature microspores; MS: mature spores; N: spore nucleus; PF: polar filament; Pp: polaroplast; PV: posterior vacuole; Sb: early sporoblast; Wa: spore wall.

\section{Declarations}

\section{Acknowledgements}

The authors thank the staff of the Servei Central de Suport a la Investigació Experimental (University of Valencia) for their support during this study. ABT were cultured in the frame of the PARACIEN project (RTC-2016-5835-2, Spanish Research Agency). We are grateful to Rachel V. Pool (University of Valencia) for revising the English.

\section{Authors' contributions}

AL-V developed the study, undertook the morphological characterisation, carried out the sequencing, performed the phylogenetic analyses. FEM supervised the manuscript, defined the general structure, and planned the project. FdG and MAG obtained the samples and conceived the study. AO was the responsible for the ABT ongrowing study. JAR took part in the preparation of the manuscript and discussed the results. JP-A coordinated and co-designed the project, supervised the sequencing and phylogenetic analyses and drafted the manuscript. All authors read and approved the final manuscript.

\section{Funding}

This study was supported by the projects TREPAQUAMED (PID2019-110730RB-I00, Ministry of Science and Innovation, Spanish Government/UE), ANITEST PLEAMAR (Biodiversity Foundation, Ministry for the Ecological Transition and the Demographic Challenge/UE) and PARACIEN (RTC-2016-5835-2, Spanish Research Agency).

\section{Availability of data and materials}

All data generated or analyzed during this study are included in this published article. The newly generated sequence was submitted to the GenBank database under the accession number \#\#\#\#\#. The holotype and paratype of G. thunni sp. nov. have been deposited in the Spanish Museum of Natural Sciences (MNCN-CSIC), Madrid, Spain (\#\#\#\#\#\#\# and \#\#\#\#\#\#); the remaining material is deposited in the Parasitological Collection of the Cavanilles Institute of Biodiversity and Evolutionary Biology, University of Valencia, Spain.

\section{Ethics approval and consent to participate}

Not applicable. The parasitological samples used in this study were collected from one dead Atlantic bluefin tuna from aquaculture batches destined for human consumption.

\section{Consent for publication}

Not applicable

\section{Competing interests}

The authors declare that they have no competing interests. 


\section{References}

1. Abdel-Baki AAS, Al-Quraishy S, Rocha S, Dkhil MA, Casal G, Azevedo C (2015a) Ultrastructure and phylogeny of Glugea nagelia n. sp. (Microsporidia: Glugeidae), infecting the intestinal wall of the yellowfin hind, Cephalopholis hemistiktos (Actinopterygii: Serranidae), from the Red Sea. Folia Parasitologica 62(1):1-7

2. Abdel-Baki AAS, Tamihi AF, Al-Qahtani HA, Al-Quraishy S, Mansour L (2015b) Glugea jazanensis sp. nov. infecting Lutjanus bohar in the Red Sea: Ultrastructure and phylogeny. Diseases of Aquatic Organisms 116(3):185-190

3. Antonelli L, Quilichini Y, Marchand B (2010) Sparicotyle chrysophrii (Van Beneden \& Hesse 1863) (Monogenea: Polyopisthocotylea) parasite of cultured Gilthead sea bream Sparus aurata (Linnaeus 1758) (Pisces: Teleostei) from Corsica: ecological and morphological study. Parasitology Research 107(2):389-398

4. APROMAR. 2020. Aquaculture in Spain 2020 Asociación Empresarial de Productores de Cultivos Marinos. Chiclana (Cádiz). http://www.apromar.es/content/informes-anuales.

5. Azevedo C, Abdel-Baki AAS, Rocha S, Al-Quraishy S, Casal G (2016). Ultrastructure and phylogeny of Glugea arabica n. sp. (Microsporidia), infecting the marine fish Epinephelus polyphekadion from the Red Sea. European Journal of Protistology 52(228):11-21

6. Bell AS, Aoki T, Yokoyama H (2001) Phylogenetic relationships among microsporidia based on rDNA sequence data, with particular reference to fishinfecting Microsporidium Balbiani 1884 species. Journal of Eukaryotic Microbiology 48 (3):258-265

7. Bulla LA, Cheng TC (1976) Biology of the Microsporidia, Comparative Pathobiology Vol. 1, Springer Science \& Business Media, New York

8. Canning EU, Lom J, Nicholas JP (1982) Genus Glugea Thèlohan 1891 (Phylum Microspora): redescription of the type species Glugea anomala (Moniez, 1887 ) and recognition of its sporogonic development within sporophorous vesicles (pansporoblastic membranes). Protistologica 18:193-210

9. Casal G, Rocha S, Costa G, Al-Quraishy S, Azevedo C (2016) Ultrastructural and molecular characterization of Glugea serranus n. sp., a microsporidian infecting the blacktail comber, Serranus atricauda (Teleostei: Serranidae), in the Madeira Archipelago (Portugal). Parasitology Research 115(10):39633972

10. Cheney SA, Lafranchi-Tristem NJ, Canning EU (2000) Phylogenetic relationships of Pleistophora-like microsporidia based on small subunit ribosomal DNA sequences and implications for the source of trachipleistophora hominis infections. Journal of Eukaryotic Microbiology 47(3):280-287

11. Corradi N, Keeling PJ (2009) Microsporidia: a journey through radical taxonomical revisions. Fungal Biology Reviews 23(1-2):1-8

12. Coyle CM, Weiss LM, Rhodes III LV, Cali A, Takvorian PM, Brown DF, Visvesvara GS, Xiao L, Naktin J, Young E, Gareca M, Colasante G, Wittner M (2004) Fatal myositis due to the microsporidian Brachiola algerae, a mosquito pathogen, The New England Journal of Medicine 351 (1):42-47

13. Culurgioni J, Mele S, Merella P, Addis P, Figus V, Cau A, Karakulak SF, Garippa G (2014) Metazoan gill parasites of the Atlantic bluefin tuna Thunnus thynnus (Linnaeus) (Osteichthyes: Scombridae) from the Mediterranean and their possible use as biological tags. Folia Parasitologica 61(2):148-156

14. Darriba D, Taboada GL, Doallo R, Posada D (2012) jModelTest 2: more models, new heuristics and parallel computing. Nature Methods $9: 772$

15. De la Gándara F, Ortega A, Buentello A (2016) Tuna aquaculture in Europe. In: Benetti DD, Partridge GJ, Buentello A (eds) Advances in Tuna Aquaculture. From hatchery to market, Chapter 6. Elsevier Academic Press, New York

16. Dezfuli BS, Giari L, Simoni E, Menegatti R, Shinn AP \& Manera M (2007) Gill histopathology of cultured European sea bass, Dicentrachus labrax (L.), infected with Diplectanum aequeans (Wagener 1857) Diesign 1958 (Diplectanidae: Monogenea) Parasitology Research 100(4):707-713

17. Docker MF, Devlin RH, Richard J, Khattra J, \& Kent ML (1997). Sensitive and specific polymerase chain reaction assay for detection of Loma salmonae (Microsporea). Diseases of Aquatic Organisms 29(1):41-48

18. Dyková I (2006) Philum Microspora. In: Woo PTK (eds) Fish Diseases and Disorders, Volume 1: Protozoan and Metazoan Infections. CABI Publishing, Wallingford, Oxforshire, UK

19. Edgar RC (2004) MUSCLE: Multiple sequence alignment with high accuracy and high throughput. Nucleic Acids Research 32:1792-1797

20. Edlund TD, Li J, Visvesvara GS, Vodkin MH, McLaughlin GL, Katiyar SK (1996) Phylogenetic Analysis of $\beta$-Tubulin Sequences from Amitochondrial Protozoa. Molecular Phylogenetics and Evolution 5(2):359-367

21. FAO. 2018. The State of World Fisheries and Aquaculture 2018 - Meeting the sustainable development goals. Rome

22. FAO. 2020. The State of World Fisheries and Aquaculture 2020. Sustainability in action. Rome

23. Fleurance R, Sauvegrain C, Marques A, Le Breton A, Guereaud C, Cherel Y, Wyers M (2008) Histopathological changes caused by Enteromyxum leei infection in farmed sea bream Sparus aurata. Diseases of Aquatic Organisms 79:219-228

24. Gouy M, Guindon S, Gascuel O (2010) SeaView version 4: A multiplatform graphical use interface for sequence alignment and phylogenetic tree building Molecular Biology and Evolution 27:221-224

25. Guindon S, Dufayard JF, Lefort V, Anisimova M, Hordijk W, Gascuel O (2010) New algorithms and methods to estimate maximum-likelihood phylogenies: Assessing the performance of PhyML 3.0. Syst Biol 59:307-321

26. Guindon S, Gascuel 0 (2003) A simple, fast, and accurate algorithm to estimate large phylogenies by maximum likelihood. Systematic Biology 52:696704

27. Hayward CJ, Bott NJ, Nowak BF (2009) Seasonal epizootics of sea lice, Caligus spp., on southern bluefin tuna Thunnus maccoyii (Castelnau), in a longterm farming trial. Journal of Fish Diseases 32:101-106

28. Hirt RP, Logsdon JM Jr, Healy B, Dorey MW, Doolittle WF, Embley TM (1999) Microsporidia are related to Fungi: evidence from the largest subunit of RNA polymerase II and other proteins. Proceedings of the National Academy of Science USA 96:580-585 
29. Keeling PJ, Doolittle WF (1996) Alpha-tubulin from early-diverging eukaryotic lineages and the evolution of the tubulin family. Molecular Biology and Evolution 13(10):1297-1305

30. Kent ML, Shaw RW and Sanders JL (2014) Microsporidia in Fish. In: Weiss LM, Becnel JJ (eds) Microsporidia: Pathogens of Opportunity, John Wiley \& Sons, Inc., Hoboken (NJ)

31. Kumar S, Stecher G, Tamura K (2016) MEGA7: Molecular evolutionary genetics analysis version 7.0 for bigger datasets. Molecular Biology and Evolution 3:1870-1874

32. Lloret J, Faliex E, Shulman GE, Raga JA, Sasal P, Muñoz M, Casadevall M, Ahuir-Baraja AE, Montero FE, Repullés-Albelda A, Cardinale M, Rätz HJ, Vila S and Ferrer D (2012) Fish Health and Fisheries, Implications for Stock Assessment and Management: The Mediterranean Example, Reviews in Fisheries Science 20(3):165-180

33. Lom J (2002) A catalogue of described genera and species of microsporidians parasitic in fish. Systematic Parasitology 53:81-99

34. Lom J, Dyková I (2005) Microsporidian xenomas in fish seen in wider perspective. Folia Parasitologica 52:69-81

35. Lom J, Nilsen F (2003) Fish microsporidia: Fine structural diversity and phylogeny. International Journal for Parasitology 33(2):107-127

36. Lovy J, Kostka M, Dyková I, Arsenault G, Pecková H, Wright GM, Speare DJ (2009) Phylogeny and morphology of Glugea hertwigi from rainbow smelt Osmerus mordax found in Prince Edward Island, Canada. Diseases of Aquatic Organisms 86(3):235-243

37. Maddox JV, Solter LF (1996). Long-term storage of infective microsporidian spores in liquid nitrogen. Journal of Eukaryotic Microbiology 43(3):221-225

38. Mansour L, Thabet A, Harrath AH, Al Omar S, Mukhtar A, Sayed SR, Abdel-Baki AAS (2016) New microsporidia, Glugea sardinellensis n. sp. (Microsporea, Glugeida) found in Sardinella aurita Valenciennes, 1847, collected off Tunisian coasts. Acta Protozoologica 55(4):281-290

39. Mansour L, Zhang JY, Abdel-Haleem HM, Darwish AB, Al-Quraishy S, Abdel-Baki AAS (2020) Ultrastructural description and phylogeny of a novel microsporidian, Glugea eda n. sp. from the striated fusilier, Caesio striata, in the Red Sea off Saudi Arabia. Acta Tropica 204:10533

40. Mathis A, Weber R, Deplazes P (2005). Zoonotic Potential of the Microsporidia. Clinical Microbiology Reviews 18(3):423-445

41. McNeill J, Barrie FR, Burdet HM, Demoulin V, Hawksworth DL, Marhold K, Nicolson DH, Prado J, Silva PC, Skog JE, Wiersema JH, Turland NJ (eds) (2006) International Code of Botanical Nomenclature (Vienna Code): adopted by the Seventeenth International Botanical Congress Vienna, Austria, July 2005.

Regnum Vegetabile 146, A.R.G. Gantner Verlag KG, Ruggell, Liechtenstein

42. Mladineo I, Lovy J (2011) A new xenoma-forming microsporidium infecting intestinal tract of Atlantic bluefin tuna (Thunnus thynnus). Acta Parasitologica 56(4):339-347

43. Mladineo I, Šegvić T, Petrić M (2011). Do captive conditions favor shedding of parasites in the reared Atlantic bluefin tuna (Thunnus thynnus)? Parasitology International 60(1):25-33

44. Mladineo I, Žilić J, Čanković M (2008) Health survey of Atlantic Bluefin Tuna, Thunnus thynnus (Linnaeus, 1758), Reared in Adriatic Cages from 2003 to 2006. Journal of the World Aquaculture Society 39(2):281-289

45. Munday BL, Sawada Y, Cribb T, Hayward CJ (2003) Diseases of tunas, Thunnus spp. Journal of Fish Diseases 26(4):187-206

46. Nilsen F, Endresen C, Hordvik I (1998) Molecular phylogeny of microsporidians with particular reference to species that infect the muscles of fish. Journal of Eukaryotic Microbiology 45(5):535-543

47. Ogawa, K., 2015. Diseases of cultured marine fishes caused by Platyhelminthes (Monogenea, Digenea, Cestoda). Parasitology 142:178-195

48. Ogawa K, Ishimaru K, Shirakashi S, Takami I, Grabner D (2011) Cardicola opisthorchis n. sp. (Trematoda: Aporocotylidae) from the Pacific bluefin tuna, Thunnus orientalis (Temminck \& Schlegel, 1844), cultured in Japan. Parasitology International 60:307-312

49. Olson RE (1976). Laboratory and field studies on Glugea stephani (Hagenmuller) a Microsporidian Parasite of Pleuronectid Flatfishes. The Journal of Protozoology 23(1):158-164

50. Ortega A, De la Gándara F (2017). Closing the life cycle of the Atlantic bluefin tuna Thunnus thynnus in captivity. In: Proceedings of Aquaculture Europe 17, Dubrovnik (Croatia) 17-20 October 2017: 857-858

51. Palacios-Abella JF, Rodríguez-Llanos J, Mele S, Montero FE (2015) Morphological characterisation and identification of four species of Cardicola Short, 1953 (Trematoda: Aporocotylidae) infecting the Atlantic bluefin tuna Thunnus thynnus (L.) in the Mediterranean Sea. Systematic Parasitology 91:101117

52. Palenzuela O, Redondo MJ, Cali A, Takvorian PM, Alonso-Naveiro M, Álvarez-Pellitero P, Sitjà-Bobadilla A (2014) A new intranuclear microsporidium, Enterospora nucleophila n. sp., causing an emaciative syndrome in a piscine host (Sparus aurata), prompts the redescription of the family Enterocytozoonidae. International Journal for Parasitology 44(3-4):189-203

53. Rambaut A (2012) FigTree v. 1.4. Molecular evolution, phylogenetics and epidemiology. Edinburgh, UK: University of Edinburgh, Institute of Evolutionary Biology, http://tree. bio.ed.ac.uk/software/figtree/. Accessed 20 Oct 2020.

54. Redhead SA, Kirk P, Keeling PJ, Weiss LM (2009) Proposal to amend the Code. 048-051 Proposals to exclude the phylum Microsporidia from the Code. Taxon 58(2):658-672

55. Rodríguez-Llanos J, Palacios-Abella J, Culurgioni J, Mele S, Macías D, Garibaldi F, Rodríguez-Marín E, Sanna N, Garau S, Merella P, Garippa G, Montero FE, Addis P (2015) Can the parasites of the head of juvenile Thunnus thynnus L. help to identify its nursery areas in the Mediterranean Sea? Collective Volumes of Scientific Papers ICCAT 71:1456-1461

56. Ronquist F, Huelsenbeck JP (2003) MrBayes 3: Bayesian phylogenetic inference under mixed models. Bioinformatics 19:1572-1574

57. Ryan JA, Kohler SL (2016) Distribution, prevalence, and pathology of a microsporidian infecting freshwater sculpins. Diseases of Aquatic Organisms 118:195-206 
58. Shirakashi S, Andrews M, Kishimoto Y, Ishimaru K, Okada T, Sawada Y, Ogawa K (2012) Oral treatment of praziquantel as an effective control measure against blood fluke infection in Pacific bluefin tuna (Thunnus orientalis). Aquaculture 326-329:15-19

59. Takahashi, S. and Egusa, S. (1977a) Studies on Glugea infection of the ayu, Plecoglossus altivelis I. Description of the Glugea and proposal of a new species, Glugea plecoglossi. Japanese Journal of Fisheries 11:175-182 (In Japanese)

60. Takahashi S, Egusa S (1977b) Studies on Glugea infection of the ayu, Plecoglossus altivelis III. Effect of water temperature on the development of xenoma of Glugea plecoglossi. Japanese Journal of Fisheries 11:195-200 (In Japanese)

61. Takvorian PM, Cali A (1983) Appendages associated with Glugea stephani, a microsporidian found in flounder. The Journal of Protozoology 30(2):251256

62. Tokarev YS, Voronin VN, Senderskiy IV, Issi IV (2015) The Microsporidium Glugea gasterostei Voronin 1974 (Microsporidia:Marinosporidia) from the threespined stickleback Gasterosteus aculeatus (Actinopterygii: Gasterosteiformes) as an independent species. Parazitologiia 49(2):81-92 (In Russian)

63. Turland NJ, Wiersema JH, Barrie FR, Greuter W, Hawksworth DL, Herendeen PS, Knapp S, Kusber WH, Li DZ, Marhold K, May TW, McNeill J, Monro AM, Prado J, Price MJ, Smith GF (eds.) (2018) International Code of Nomenclature for algae, fungi, and plants (Shenzhen Code): adopted by the Nineteenth International Botanical Congress Shenzhen, China, July 2017. Regnum Vegetabile 159. Glashütten: Koeltz Botanical Books.

64. Van de Peer Y, Ben Ali A, Meyer A (2000) Microsporidia: accumulating molecular evidence that a group of amitochondriate and suspectedly primitive eukaryotes are just curious fungi. Gene 246(1-2):1-8

65. Woo PTK (2006) Fish Diseases and Disorders, Volume 1: Protozoan and Metazoan Infections, 2nd edition. CABI Publishing, Wallingford, Oxfordshire, UK

66. World Register of Marine Species Database. WoRMS Editorial Board. http://www.marinespecies.org/aphia.php?p=taxdetails\&id=394215. Accessed 20 Mar 2021.

67. Wu HB, Wu YS, Wu ZH (2005) Occurrence of a new microsporidian in the abdominal cavity of Epinephelus akaara. Acta Hydrobiologica Sinica 29:150154 (In Chinese)

68. Zhang J, Meng F, Yokoyama H, Miyahara J, Takami I, Ogawa K (2010) Myxosporean and microsporidian infections in cultured Pacific bluefin tuna Thunnus orientalis in The Japanese Society of Fisheries Science 76:981-990

69. Zhang JY, Wu YS, Lu YS, Wang JG (2004): Advance in research of fish microsporidia. Acta Hydrobiologica Sinica 28:563-568 (In Chinese)

\section{Tables}

Table 1. Summary of the sequences of microsporidians used in the phylogenetic analyses retrieved from GenBank. 


\begin{tabular}{|c|c|c|c|}
\hline Parasite species & Host species & $\begin{array}{l}\text { GenBank } \\
\text { accession no. }\end{array}$ & Reference \\
\hline Glugea anomala (Moniez, 1887) & Gasterosteus aculeatus L. & AF044391 & Nilsen et al. (1998) \\
\hline $\begin{array}{l}\text { Glugea arabica Azevedo, Abdel-Baki, Rocha, Al-Quraishy \& } \\
\text { Casal, } 2016\end{array}$ & $\begin{array}{l}\text { Epinephelus polyphekadion } \\
\text { (Bleeker, 1849) }\end{array}$ & КT005391 & Azevedo et al. (2016) \\
\hline Glugea atherinae Berrebi, 1979 & Atherina boyeri Risso, 1810 & U15987 & $\begin{array}{l}\text { Da Silva et al. (unpublished } \\
\text { data) }\end{array}$ \\
\hline $\begin{array}{l}\text { Glugea eda Mansour, Zhang, Abdel-Haleem, Darwish, Al- } \\
\text { Quraishy, Abdel-Baki, } 2020\end{array}$ & Caesio striata Rüppell, 1830 & MK568064 & Mansour et al. (2020) \\
\hline Glugea epinephelusis Wu, Wu, Wu, 2005 & $\begin{array}{l}\text { Epinephelus akaara (Temminck \& } \\
\text { Schlegel, 1842) }\end{array}$ & AY090038 & Wu et al. (2005) \\
\hline Glugea gasterostei Voronin, 1974 & Gasterosteus aculeatus L. & KM977990 & Tokarev et al. (2015) \\
\hline Glugea hertwigi Weissenberg, 1911 & Osmerus eperlanus eperlanus (L.) & GQ203287 & Lovy et al. (2009) \\
\hline $\begin{array}{l}\text { Glugea jazanensis Abdel-Baki, Tamihi, Al-Qahtani, Al-Quraishy, } \\
\text { Mansour, } 2015\end{array}$ & Lutjanus bohar (Forsskål, 1775) & KP262018 & Abdel-Baki et al. (2015b) \\
\hline $\begin{array}{l}\text { Glugea nagelia Abdel-Baki, Al-Quraishy, Rocha, Dkhil, Casal, } \\
\text { Azevedo, } 2015\end{array}$ & $\begin{array}{l}\text { Cephalopholis hemistiktos } \\
\text { (Rüppell, 1830) }\end{array}$ & KJ802012 & Abdel-Baki et al. (2015a) \\
\hline Glugea plecoglossi Strickland, 1911 & $\begin{array}{l}\text { Plecoglossus altivelis (Temminck \& } \\
\text { Schlegel, 1846) }\end{array}$ & AJ295326 & Bell et al. (2001) \\
\hline $\begin{array}{l}\text { Glugea sardinellensis Mansour, Thabet, Harrath, Al Omar, } \\
\text { Mukhtar, Sayed, Abdel-Baki, } 2016\end{array}$ & Sardinella aurita (Valenciennes) & KU577431 & Mansour et al. (2016) \\
\hline $\begin{array}{l}\text { Glugea serranus Casal, Rocha, Costa, Al-Quraishy, Azevedo, } \\
2016\end{array}$ & Serranus atricauda Günther, 1874 & KU363832 & Casal et al. (2016) \\
\hline Glugea stephani (Hagenmüller 1899) & Platichthys flesus (L.) & AF056015 & $\begin{array}{l}\text { Pomport-Castillon et al. } \\
\text { (unpublished data) }\end{array}$ \\
\hline Glugea thunnisp. nov. & Thunnus thynnus (L.) & $X X X X X X$ & This study \\
\hline $\begin{array}{l}\text { Loma embiotocia Shaw, Kent, Docker, Brown, Devlin, Adamson, } \\
1997\end{array}$ & $\begin{array}{l}\text { Cymatogaster aggregata Gibbons, } \\
1854\end{array}$ & AF320310 & Brown (unpublished data) \\
\hline Loma morhua Morrison, Sprague, 1981 & Gadus morhua L. & GQ121037 & $\begin{array}{l}\text { Frenette et al. (unpublished } \\
\text { data) }\end{array}$ \\
\hline Loma salmonae (Putz, Hoffman, Dunbar, 1965) & $\begin{array}{l}\text { Oncorhynchus mykiss (Walbaum, } \\
\text { 1792) }\end{array}$ & U78736 & Docker et al. (1997) \\
\hline $\begin{array}{l}\text { Microgemma caulleryi Leiro J, Sanmartin M, Iglesias R \& Ubeira } \\
\text { F, 1999* }\end{array}$ & $\begin{array}{l}\text { Hyperoplus lanceolatus (Le } \\
\text { Sauvage) }\end{array}$ & AY033054 & $\begin{array}{l}\text { Leiro et al. (unpublished } \\
\text { data) }\end{array}$ \\
\hline Microgemma sp. partial 16S & - & AJ252952 & Cheney et al. (2000) \\
\hline Pleistophora ehrenbaumi Reichenow, 1929 & Anarhichas lupus L. & AF044392 & Nilsen et al. (1998) \\
\hline Pleistophora mirandellae Vaney \& Conte, 1901 & Rutilus rutilus (L.) & AJ295327 & Bell et al. (2001) \\
\hline Pleistophora typicalis Gurley, 1893 & Myoxocephalus scorpius (L.) & AF044387 & Nilsen et al. (1998) \\
\hline \multicolumn{4}{|l|}{ Outgroup } \\
\hline Brachiola algerae Vavra \& Undeen, 1970 & Anopheles stephensi Liston 1901 & AY230191 & Coyle et al. (2004) \\
\hline
\end{tabular}


Table 2. Differences among representatives of the genera Brachiola, Glugea, Loma, Microgemma and Pleistophora for 16S rDNA sequences, pairwise nucleotide differences (above the diagonal) and p-distances (below the diagonal) 774bp sequences.

\begin{tabular}{|c|c|c|c|c|c|c|c|c|c|c|c|c|c|c|c|c|}
\hline & Species & 1 & 2 & 3 & 4 & 5 & 6 & 7 & 8 & 9 & 10 & 11 & 12 & 13 & 14 & 15 \\
\hline 1 & $\begin{array}{l}\text { Brachiola } \\
\text { algerae }\end{array}$ & - & 206 & 197 & 205 & 200 & 200 & 204 & 205 & 197 & 198 & 204 & 210 & 197 & 205 & 205 \\
\hline 2 & $\begin{array}{l}\text { Glugea } \\
\text { anomala }\end{array}$ & 0.315 & - & 60 & 2 & 58 & 62 & 2 & 2 & 61 & 62 & 1 & 18 & 61 & 4 & 2 \\
\hline 3 & $\begin{array}{l}\text { Glugea } \\
\text { Arabica }\end{array}$ & 0.302 & 0.090 & - & 58 & 4 & 3 & 58 & 58 & 1 & 1 & 59 & 69 & 1 & 60 & 58 \\
\hline 4 & $\begin{array}{l}\text { Glugea } \\
\text { atherinae }\end{array}$ & 0.313 & 0.003 & 0.086 & - & 56 & 60 & 0 & 0 & 59 & 60 & 1 & 16 & 59 & 2 & 0 \\
\hline 5 & Glugea eda & 0.306 & 0.087 & 0.006 & 0.083 & - & 5 & 56 & 56 & 5 & 5 & 57 & 67 & 5 & 58 & 56 \\
\hline 6 & $\begin{array}{l}\text { Glugea } \\
\text { epinephelusis }\end{array}$ & 0.306 & 0.093 & 0.004 & 0.089 & 0.007 & - & 60 & 60 & 4 & 4 & 61 & 71 & 4 & 62 & 60 \\
\hline 7 & $\begin{array}{l}\text { Glugea } \\
\text { gasterostei }\end{array}$ & 0.311 & 0.003 & 0.087 & 0.000 & 0.083 & 0.089 & - & 0 & 59 & 60 & 1 & 16 & 59 & 2 & 0 \\
\hline 8 & $\begin{array}{l}\text { Glugea } \\
\text { hertwigi }\end{array}$ & 0.313 & 0.003 & 0.086 & 0.000 & 0.083 & 0.089 & 0.000 & - & 59 & 60 & 1 & 16 & 59 & 2 & 0 \\
\hline 9 & $\begin{array}{l}\text { Glugea } \\
\text { jazanensis }\end{array}$ & 0.301 & 0.091 & 0.001 & 0.088 & 0.007 & 0.006 & 0.088 & 0.088 & - & 2 & 60 & 70 & 2 & 61 & 59 \\
\hline 10 & $\begin{array}{l}\text { Glugea } \\
\text { nagelia }\end{array}$ & 0.303 & 0.093 & 0.001 & 0.089 & 0.007 & 0.006 & 0.089 & 0.089 & 0.003 & - & 61 & 71 & 2 & 62 & 60 \\
\hline 11 & $\begin{array}{l}\text { Glugea } \\
\text { plecoglossi }\end{array}$ & 0.311 & 0.001 & 0.088 & 0.001 & 0.085 & 0.091 & 0.001 & 0.001 & 0.089 & 0.091 & - & 17 & 60 & 3 & 1 \\
\hline 12 & $\begin{array}{l}\text { Glugea } \\
\text { sardinellensis }\end{array}$ & 0.325 & 0.027 & 0.105 & 0.024 & 0.101 & 0.107 & 0.024 & 0.024 & 0.106 & 0.107 & 0.026 & - & 70 & 18 & 16 \\
\hline 13 & $\begin{array}{l}\text { Glugea } \\
\text { serranus }\end{array}$ & 0.301 & 0.091 & 0.001 & 0.088 & 0.007 & 0.006 & 0.088 & 0.088 & 0.003 & 0.003 & 0.089 & 0.106 & - & 61 & 59 \\
\hline 14 & $\begin{array}{l}\text { Glugea } \\
\text { stephani }\end{array}$ & 0.313 & 0.006 & 0.089 & 0.003 & 0.086 & 0.092 & 0.003 & 0.003 & 0.091 & 0.092 & 0.004 & 0.027 & 0.091 & - & 2 \\
\hline 15 & $\begin{array}{l}\text { Glugea } \\
\text { thunnisp. } \\
\text { nov. }\end{array}$ & 0.313 & 0.003 & 0.086 & 0.000 & 0.083 & 0.089 & 0.000 & 0.000 & 0.088 & 0.089 & 0.001 & 0.024 & 0.088 & 0.003 & - \\
\hline 16 & $\begin{array}{l}\text { Loma } \\
\text { embiotocia }\end{array}$ & 0.322 & 0.154 & 0.158 & 0.150 & 0.159 & 0.164 & 0.150 & 0.150 & 0.159 & 0.161 & 0.152 & 0.171 & 0.161 & 0.153 & 0.150 \\
\hline 17 & $\begin{array}{l}\text { Loma } \\
\text { morhua }\end{array}$ & 0.325 & 0.133 & 0.145 & 0.129 & 0.145 & 0.149 & 0.129 & 0.129 & 0.145 & 0.146 & 0.131 & 0.151 & 0.146 & 0.132 & 0.129 \\
\hline 18 & $\begin{array}{l}\text { Loma } \\
\text { salmonae }\end{array}$ & 0.324 & 0.136 & 0.145 & 0.132 & 0.145 & 0.149 & 0.133 & 0.132 & 0.154 & 0.146 & 0.134 & 0.153 & 0.146 & 0.135 & 0.132 \\
\hline 19 & $\begin{array}{l}\text { Microgemma } \\
\text { caulleryi* }\end{array}$ & 0.307 & 0.169 & 0.184 & 0.167 & 0.185 & 0.188 & 0.166 & 0.167 & 0.185 & 0.187 & 0.167 & 0.188 & 0.185 & 0.170 & 0.167 \\
\hline 20 & $\begin{array}{l}\text { Microgemma } \\
\text { sp. partial } \\
16 S\end{array}$ & 0.298 & 0.182 & 0.175 & 0.179 & 0.179 & 0.181 & 0.177 & 0.179 & 0.176 & 0.177 & 0.179 & 0.197 & 0.176 & 0.182 & 0.179 \\
\hline 21 & $\begin{array}{l}\text { Pleistophora } \\
\text { ehrenbaumi }\end{array}$ & 0.319 & 0.113 & 0.109 & 0.112 & 0.106 & 0.112 & 0.112 & 0.112 & 0.107 & 0.110 & 0.11 & 0.129 & 0.109 & 0.115 & 0.112 \\
\hline 22 & $\begin{array}{l}\text { Pleistophora } \\
\text { mirandellae }\end{array}$ & 0.331 & 0.106 & 0.105 & 0.104 & 0.108 & 0.111 & 0.104 & 0.104 & 0.108 & 0.108 & 0.106 & 0.124 & 0.106 & 0.107 & 0.104 \\
\hline 23 & $\begin{array}{l}\text { Pleistophora } \\
\text { typicalis }\end{array}$ & 0.323 & 0.117 & 0.110 & 0.115 & 0.106 & 0.112 & 0.115 & 0.115 & 0.108 & 0.111 & 0.115 & 0.134 & 0.109 & 0.118 & 0.115 \\
\hline
\end{tabular}

Table 3. Differences among representatives of the genera Brachiola, Glugea, Loma and Pleistophora for 16S rDNA sequences, pairwise nucleotide differences (above the diagonal) and p-distances (below the diagonal) 1713bp sequences. 


\begin{tabular}{|llllllllllll|}
\hline & Species & 1 & 2 & 3 & 4 & 5 & 6 & 7 & 8 & 9 & 10 \\
\hline 1 & Brachiola algerae & - & 479 & 471 & 470 & 473 & 474 & 473 & 474 & 501 & 493 \\
\hline 2 & Glugea anomala & 0.320 & - & 152 & 149 & 17 & 155 & 151 & 14 & 242 & 205 \\
\hline 3 & Glugea arabica & 0.314 & 0.097 & - & 16 & 142 & 12 & 11 & 142 & 231 & 182 \\
\hline 4 & Glugea eda & 0.315 & 0.096 & 0.010 & - & 139 & 12 & 7 & 139 & 230 & 176 \\
\hline 5 & Glugea hertwigi & 0.316 & 0.011 & 0.091 & 0.089 & - & 145 & 141 & 7 & 234 & 200 \\
\hline 6 & Glugea nagelia & 0.316 & 0.099 & 0.008 & 0.008 & 0.092 & - & 7 & 145 & 235 & 175 \\
\hline 7 & Glugea serranus & 0.315 & 0.096 & 0.007 & 0.004 & 0.090 & 0.004 & - & 141 & 231 & 174 \\
\hline 8 & Glugea thunnisp. nov. & 0.316 & 0.009 & 0.091 & 0.089 & 0.004 & 0.092 & 0.090 & - & 236 & 197 \\
\hline 9 & Loma embiotocia & 0.334 & 0.155 & 0.148 & 0.148 & 0.149 & 0.150 & 0.147 & 0.151 & - & 277 \\
\hline 10 & Pleistophora ehrenbaumi & 0.330 & 0.131 & 0.117 & 0.113 & 0.128 & 0.112 & 0.111 & 0.126 & 0.177 & - \\
\hline
\end{tabular}

\section{Figures}

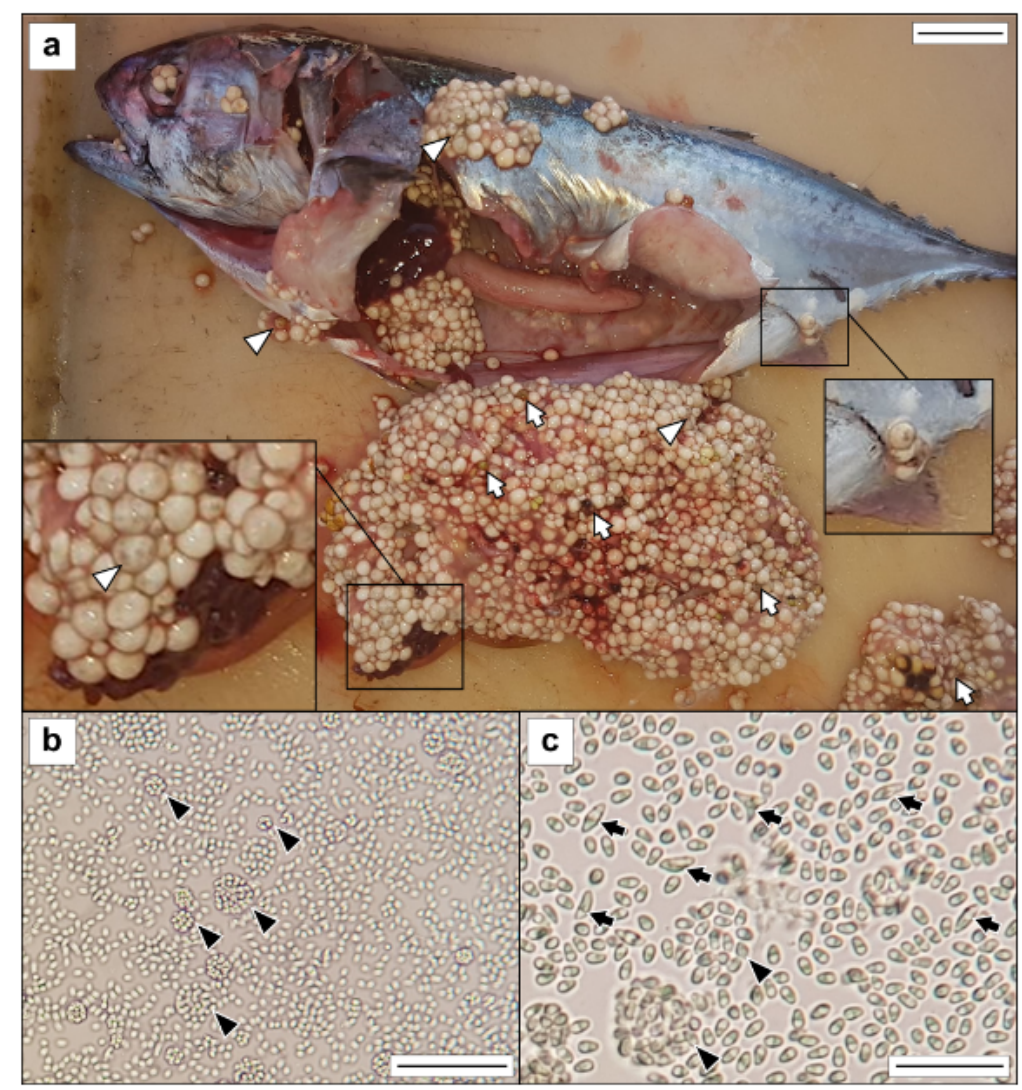

\section{Figure 1}

Glugea thunni sp. nov. in Thunnus thynnus from the Mediterranean Sea. a) Specimen of T. thynnus infected by G. thunni sp. nov. with melanized and partially melanized cysts, including a detail of cysts within the ceacal mass (scale bar $2.5 \mathrm{~cm}$ ) b) Fresh smear with free microspores and parasitophorous vesicles with different number of microspores (scale bar $40 \mu \mathrm{m}$ ). c) Detail of fresh smear with free short and large microspores and parasitophorous vesicles (scale bar 20 $\mu \mathrm{m})$. White arrow - melanized cyst; white arrowhead - cysts with melanized spots; black arrows - abnormal microspores; black arrowheads parasitophorous vesicles. 


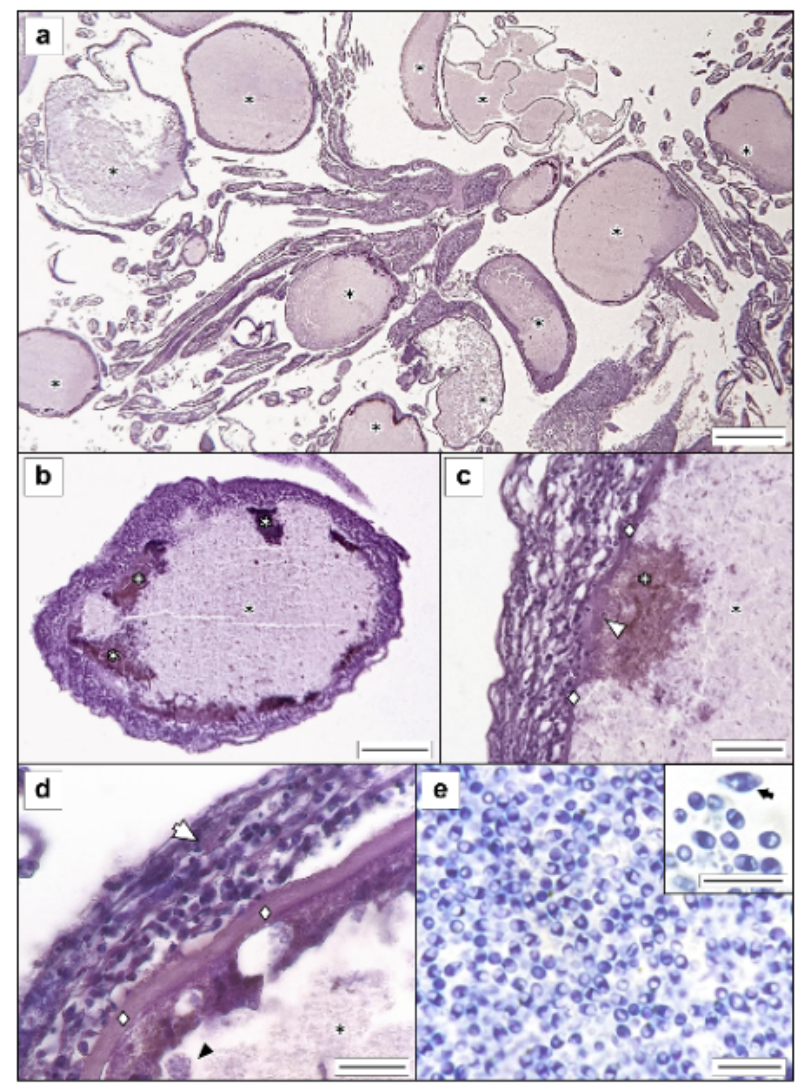

Figure 2

Micrographs of Glugea thunni sp. nov. from histological sections of the caecal mass of Thunnus thynnus from the Mediterranean Sea. a) G. thunni sp. nov. cysts in the mesentery among the intestinal caeca (scale bar $1 \mathrm{~mm}$ ). b) Cyst of G. thunni sp. nov.; xenoma exhibits peripheral spots with different degrees of melanization (scale bar $200 \mu \mathrm{m}$ ). c) Detail of peripheral xenome melanization (scale bar $70 \mu \mathrm{m}$ ). d) Cyst wall with eosinophilic granule cell in the outer celular layer (scale bar $40 \mu \mathrm{m})$. e) Microspores at the central region of xenome (scale bar $10 \mu \mathrm{m})$ with a detail including an abnormal microspore (scale bar $5 \mu \mathrm{m})(\mathrm{a}-\mathrm{d}$, paraffin sections stained in $\mathrm{H}-\mathrm{W}$; e, semi-thin stained in toluidine blue). White arrow - eosinophilic granule cell; black asterisk - cyst/xenoma; white asterisk melanized spot; white diamond - acellular/fibrous layer; white arrowhead - disintegrated acellular/fibrous layer; black arrowhead - parasitophorus vesicle. 


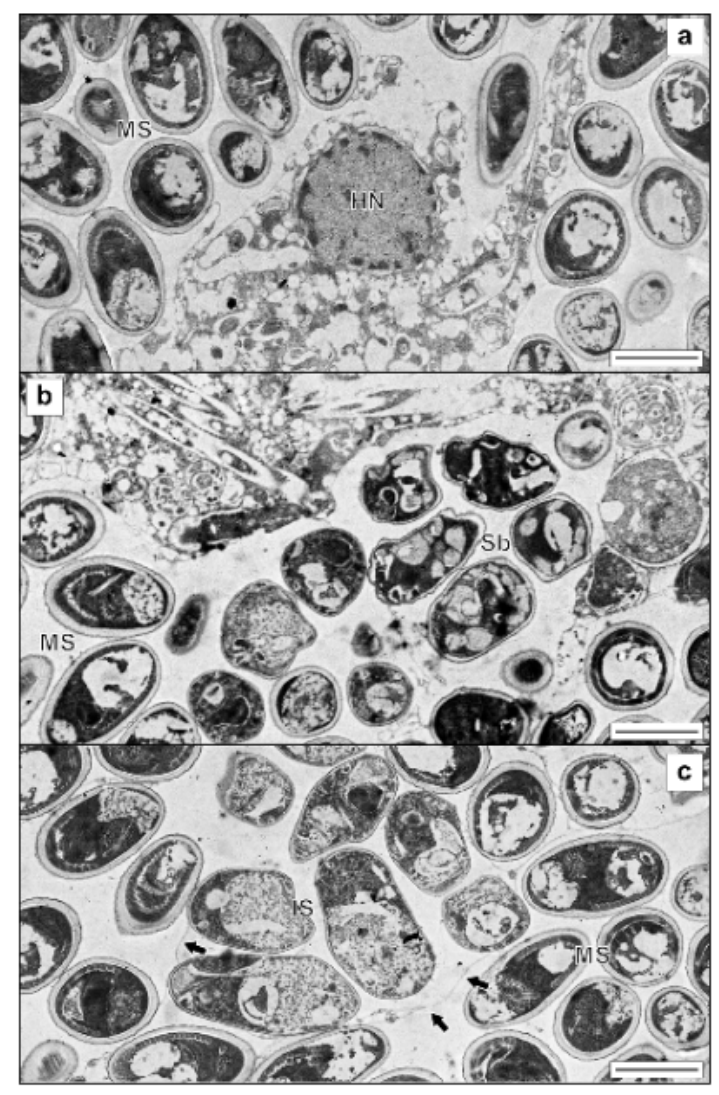

Figure 3

Transmission electron micrographs of xenomas of Glugea thunni sp. nov. from the caecal mass of Thunnus thynnus from the Mediterranean Sea. a) Mature spores and degenerative host cells. b) and c) Spores under development. MS - mature spores; IS - immature spores; Sb - Early sporoblast; HN, Host cell nucleus; black arrowhead - parasitophorous vacuole membrane. (scale bars $2 \mu \mathrm{m}$ ).

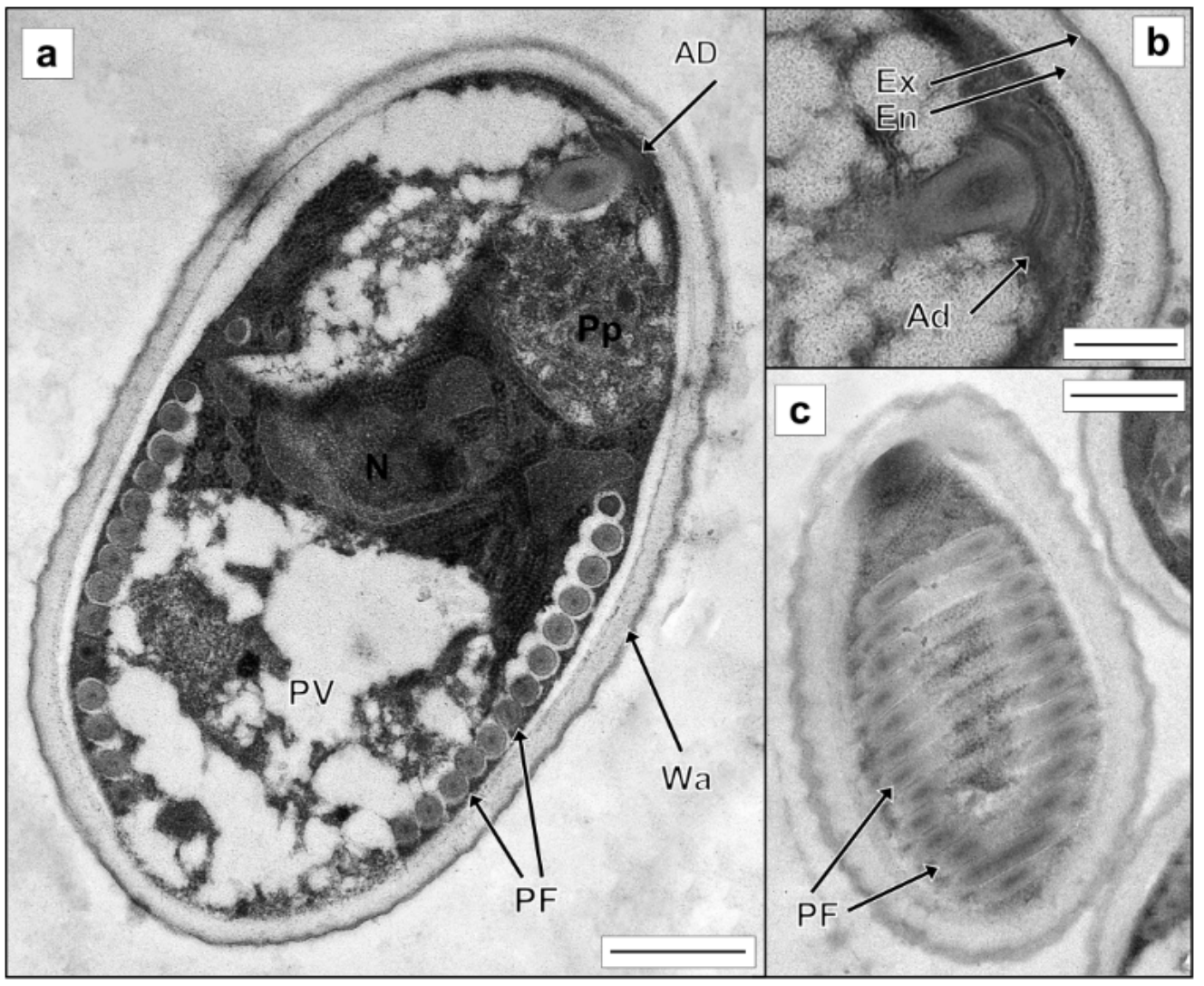

Figure 4 
Transmission electron micrographs of Glugea thunni sp. nov. from the caecal mass of Thunnus thynnus from the Mediterranean Sea. a) Longitudinal section of an adult microspore showing the ultrastructure (scale bar $500 \mathrm{~nm}$ ). b) Detail of the anchoring disk and spore wall (scale bar $400 \mathrm{~nm}$ ). c) Detail of polar filament surrounding the spore (scale bar $1 \mu \mathrm{m}$ ). Abbreviations: AD - anchoring disk; En - wall endospore; Ex - wall exospore; $N$ - spore nucleus; PF - polar filament; Pp - polaroplast; PV - posterior vacuole; Wa - spore wall.

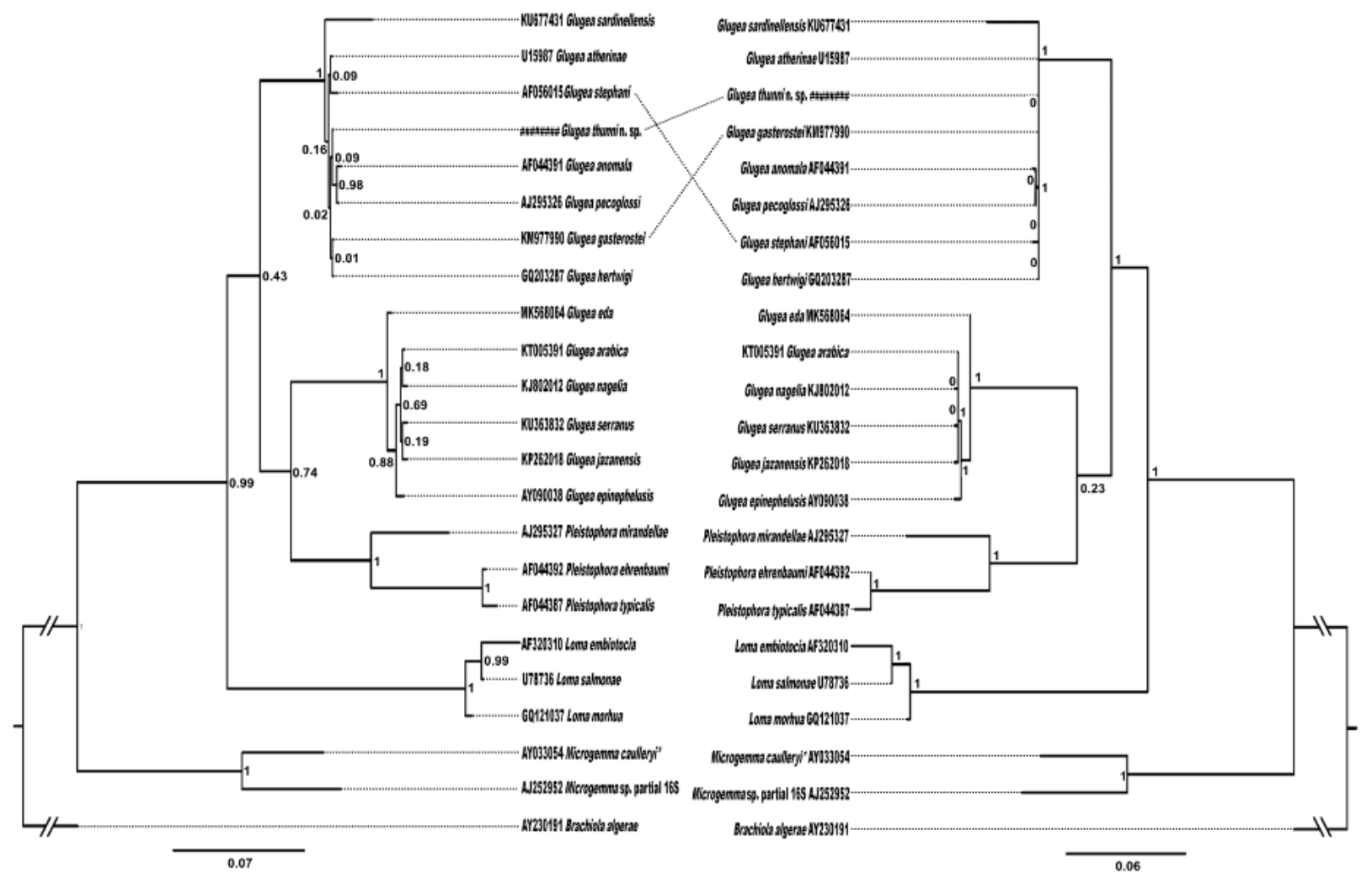

Figure 5

Confronted bayesian inference $(\mathrm{BI})$ and maximum likelihood $(\mathrm{ML})$ trees for the analyses of the microsporidians based on partial 16S rDNA sequences (774bp). Nodal support is given as posterior probabilities $(\mathrm{BI})$ and bootstrap values resulting from maximum likelihood ( $\mathrm{ML}$ ); only values $>0.95$ ( $\mathrm{BI}$ ) and $70 \%$ $(\mathrm{ML})$ are shown. The scale-bars indicate the expected number of substitutions per site. *Microgemma caulleryi is accepted as G. microspora in Lom 2002.

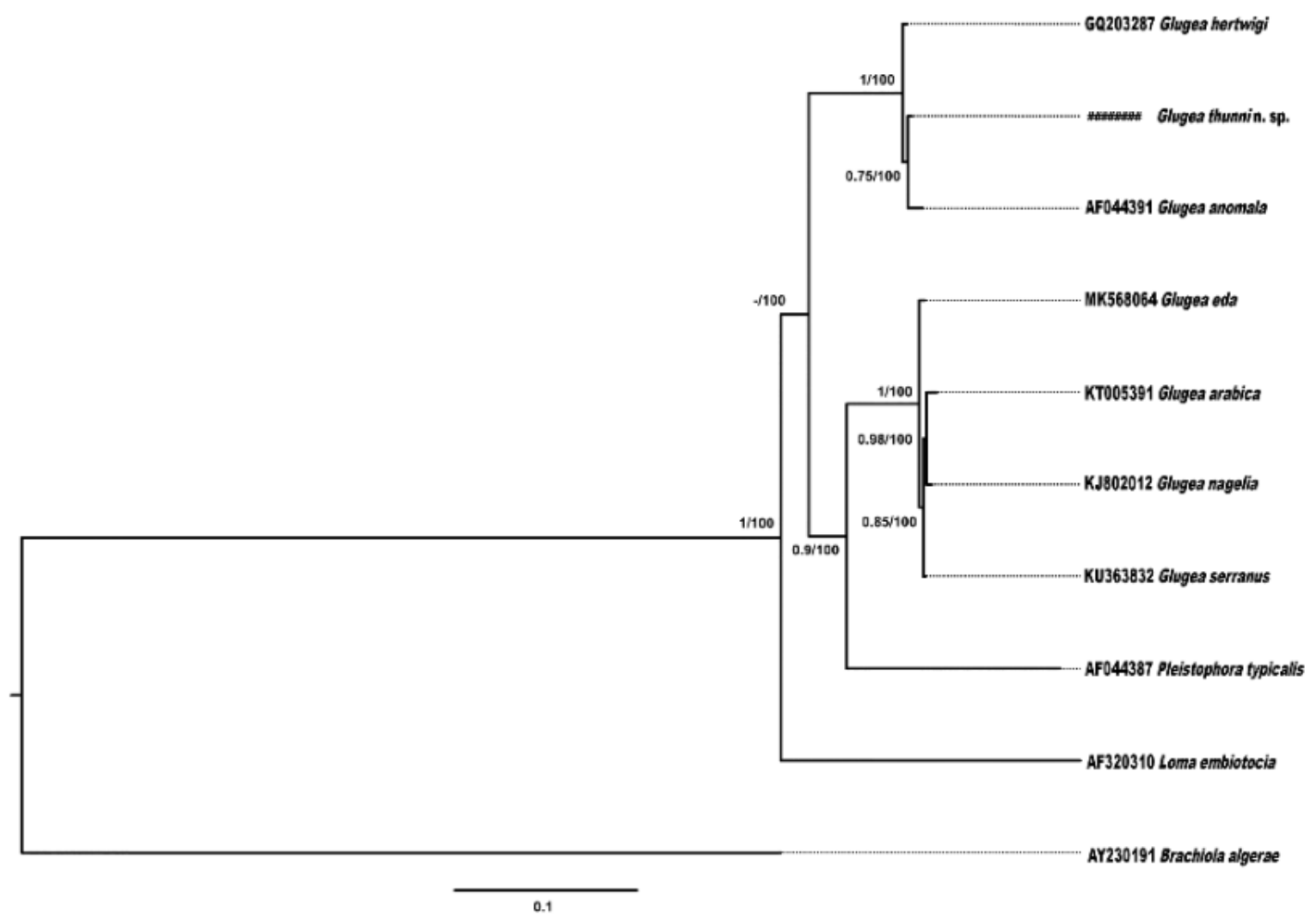


Figure 6

Resulting tree for the analyses of the microsporidians based on partial 16S rDNA sequences (1713bp). Nodal support is given as posterior probabilities (BI) and bootstrap values resulting from maximum likelihood $(\mathrm{ML})$ analysis in the form (BI/ML); only values $>0.95(\mathrm{BI})$ and $70 \%(\mathrm{ML})$ are shown. The scale-bar indicates the expected number of substitutions per site. 